Cezary Kosikowski (ed.)

\title{
PRZYSZŁOŚĆ UNII EUROPEJSKIEJ W ŚWIETLE JEJ USTROJU WALUTOWEGO I FINANSOWEGO (THE FUTURE OF THE EUROPEAN UNION IN THE LIGHT ITS CURRENCY AND FINANCIAL REGIME)
}

\author{
Publisher: Temida 2, Biatystok 2013 (pp. 350)
}

The purpose of the publication is to answer the questions of whether, in the light of the laws in force in the EU since 2009 regarding the currency and financial regime, continued functioning and development of the $\mathrm{EU}$ is possible and whether the existence of the EU is in danger and the organization requires further reforms (p. 7). Attempts to answer those questions were made by lawyers and economists from numerous Polish academic centers, with the participations of specialists from Slovakia. The specific problems and the structure of the work are indicated by the titles of the individual articles:

- Financial condition of the European Union and its members on the eve of adoption of the new financial framework for the years 2014-2020 (K. Piotrowska-Marczak);

- The condition of Spain's public finances after accession to the Eurozone (J. Marczak);

- The condition of public finances in Slovakia as a Eurozone member state (V. Babčák);

- The condition of public finances in Poland as a country subject to derogation (J. Stankiewicz);

- The problem of limits and forms of EU interventionism in the area of currencies and public finances of member states (C. Kosikowski);

- On non-implemented legislative projects in EU tax law (B. Brzeziński);

- A new approach to the problem of macroeconomic balance, deficit and sovereign debt in EU member states in the light of the modification of the Stability and Growth Pact and the Fiscal Pact (M. Fedorowicz); 
- The EU financial framework for the years 2014-2020 and the reform of the EU general budget (T. Nieborak);

- Further possibility for EU member states to use money from European funds and money arising from EU initiatives and to use EU financial instruments and mechanisms (M. Perkowski);

- Prospects for use of European funds by units of territorial self-government and the problem of return of such funds (J. M. Salachna);

- Financial aid from the European Union to member states - European Stability Mechanism (A. Piekutowska);

- Changes to present legal solutions in the area of supervision of the financial markets in the European Union - selected problems (M. Olszak);

- New bodies and institutions for security of the financial market in the European Union (A. Jurkowska-Zeidler);

- The future of the euro as the European currency (T. Machelski).

Although the comments and conclusions presented in the individual articles deserve a more detailed discussion, I would like to only indicate a few general statements made in the conclusion of the work and formulated by its scientific editor. In his opinion, even before the financial crisis, the EU was institutionally and functionally ineffective and its member states had to make their own responses to the economic and financial crisis as the EU's response was late and focused mostly on the Eurozone countries. The new anti-crisis solutions adopted by the EU bring new valuable elements. Nevertheless, the EU continues to focus its activities on the situation in the member states of the Eurozone. As a result, the division of the EU into two groups of states becomes deeper (the so-called "Union of two speeds"). This is why "in the light of the presented evidence, the future of the EU is not so clear and sure. There is more evidence indicating that the EU will be a Union of "two speeds" than evidence indicating that the EU will have no such characteristics and will be full of natural and effective social and economic integration of most countries of Europe" (p. 348). This is certainly a real danger. However, one must emphasize that other scientific research conducted in the Białystok's center of financial law science emphasizes continued integration of financial institutions and procedures in the EU. Of great importance to this integration are methods of both direct and indirect ("soft") influence on the member states. Their effectiveness will only be known in a few years because, on the one hand, they enable solving current problems and, on the other hand, result in new conflicts and problems. The results of 
this research should be known to representatives of European institutions, so as both to enable optimized decision making and to initiate research in the area in question.

Prof. dr hab. Eugeniusz Ruśkowski

University of Biatystok 